DOI: https://doi.org/10.47405/mjssh.v6i7.854

\begin{tabular}{|c|c|}
\hline 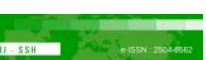 & Malaysian Journal of Social Sciences and Humanities (MJSSH) \\
\hline Malaysian Journal of & Volume 6, Issue 7, July 2021 \\
\hline (mJ-ssH) & e-ISSN : 2504-8562 \\
\hline & $\begin{array}{l}\text { Journal home page: } \\
\text { www.msocialsciences.com }\end{array}$ \\
\hline
\end{tabular}

\title{
Cabaran Guru dalam Melaksanakan Pengajaran dan Pembelajaran di Rumah (PdPR): Suatu Pemerhatian Awal
}

\author{
Norehan Binti Mohd Nasir¹, Mahaliza Binti Mansor ${ }^{1}$ \\ 1Fakulti Pengurusan dan Ekonomi, Universiti Pendidikan Sultan Idris (UPSI) \\ Correspondence: Norehan Binti Mohd Nasir (norehan.upsi@gmail.com)
}

\begin{abstract}
Abstrak
Profesion perguruan adalah tunggak utama negara dalam membentuk kemenjadian insan yang cemerlang. Guru sebagai pemudahcara pengajaran berfungsi sepenuhnya untuk memastikan penyampaian ilmu yang telus dan berkualiti kepada segenap lapisan murid. Krisis kesihatan global Covid-19 yang melanda dunia hari ini telah mendatangkan pelbagai impak kepada ekonomi, sosial dan politik sesebuah negara termasuklah bidang pendidikan. Walaupun terdapat pelbagai cabaran yang dihadapi, namun kajian ini menumpukan kepada cabaran guru dalam melaksanakan Pengajaran dan Pembelajaran di Rumah (PdPR) dengan menggunakan sumber literatur dan kajian-kajian lepas.
\end{abstract}

Kata kunci: cabaran PdPR, teknologi, ibu bapa, guru

\section{Teacher Challenges in Implementing Home Teaching and Learning (PdPR): A Preliminary Observation}

\begin{abstract}
The teaching profession is the main pillar of the country in shaping the future of excellent human beings. Teachers as teaching facilitators function fully to ensure the delivery of transparent and quality knowledge to all levels of students. The Covid-19 global visibility crisis that has hit the world today has had various impacts on the economy, society and politics of a country, including the field of education. Although there are various challenges faced, but this study focuses on the challenges of teachers in implementing Teaching and Learning at Home (PdPR) by using literature sources and previous studies.
\end{abstract}

Keywords: PdPR challenges, technology, parents, teachers

\section{Pengenalan}

Pelan Pembangunan Pendidikan Malaysia (2013-2025) telah menetapkan setiap murid mendapat akses kepada pendidikan untuk mencapai potensi diri bagi menghadapi kehidupan masa hadapan. Pendidikan boleh dijalankan sama ada secara bersemuka dalam kelas dengan guru atau secara terpisah tanpa guru. Masyarakat lazimnya menerima pendidikan secara bersemuka dengan guru dan guru harus berada di dalam kelas mengajar muridnya. Keberhasilan pembelajaran murid menerusi PdPR ini merupakan fokus 
utama dalam refleksi pengajaran. Guru sebagai pemudahcara perlu memastikan pembelajaran dan pengajaran dapat dilaksanakan tanpa sebarang halangan dengan strategi pengajaran yang berpusatkan murid dan bahan pembelajaran.

Pendidikan menjadi semakin moden dalam menghadapi cabaran dunia yang semakin membangun (Mary Yap Kain Ching, 2015). Kementerian Pendidikan Malaysia (KPM) telah lama memperkenalkan konsep pembelajaran secara maya iaitu melalui pengenalan konsep Sekolah Bestari pada tahun 1996, serta Pembestarian Sekolah dan laman Frog VLE pada tahun 2006 (Roshlawaty, 2020). Konsep dan kaedah pembelajaran ini telah berkembang dan diterima oleh masyarakat ketika penularan wabak virus COVID19 bermula pada penghujung tahun 2019. Pandemik Covid-19 sebenarnya telah mempercepatkan penerimaan masyarakat negara ini terhadap pembelajaran secara maya yang sebelum ini dijangka mengambil masa yang lebih lama untuk diadaptasi (Ima \& Adam, 2020).

Perkara ini seiring dengan Pelan Pembangunan Pendidikan Malaysia (2013-2025) yang dalam anjakan pertamanya iaitu 'menyediakan kesamarataan akses kepada pendidikan berkualiti bertaraf antarabangsa serta anjakan keenam dalam memanfaatkan teknologi komunikasi dan maklumat (ICT) bagi meningkatkan kualiti pembelajaran di Malaysia. Selaras dengan usaha itu, KPM telah memperkenalkan satu pelantar pendidikan yang dinamakan sebagai Digital Educational Learning Initiative Malaysia (DELIMa) yang bertujuan untuk membantu dan memudahkan para guru menyampai pengajaran dengan menyediakan pautan link kepada Google Classroom, Microsoft Teams, Buku Teks Digital, EduwebTV, CikgooTube, aplikasi pembelajaran dan pautan aplikasi gamifikasi yang dapat membantu PdPc. Dalam usaha ini juga, KPM juga telah menganjurkan pelbagai kursus bagi menyediakan guru dengan kemahiran menggunakan pelantar pembelajaran secara digital serta membina pelbagai bahan pembelajaran bagi membantu pelaksanaan PdPR. Antaranya melalui saluran RTM Okey iaitu TV Pendidikan dan ASTRO Tutor TV. Pembelajaran secara dalam talian telah mendedahkan pelajar kepada pelbagai jenis aplikasi dan teknologi terkini yang mempunyai pelbagai faedah pengajaran dan pembelajaran. Nor Hayati (2020) menyatakan pembelajaran sepanjang hayat (Life Long Learning) dengan pembelajaran secara dalam talian boleh menghasilkan individu yang mempunyai kemahiran.

Pemimpin merupakan individu yang perlu mengambil inisiatif untuk membawa perubahan dalam sistem pendidikan bagi mencapai matlamat sekolah yang telah ditetapkan (Niqab, Sharma, Wei \& Maulod (2014). Inisiatif perubahan yang dilaksanakan mestilah selaras dengan perkembangan pendidikan masa kini. Pengetua yang bertindak sebagai pemimpin instruksional di sekolah perlu merancang tindakan strategik dan holistik bagi mengatasi masalah penglibatan murid di dalam kelas secara dalam talian bagi meningkatkan pencapaian murid. Ini berikutan dalam kajian yang dijalankan oleh Hallinger \& Heck, (1995); Waters, Marzano \& cNulty, (2003); Fullan, (2007); Leithwood, Harris, \& Hopkins (2006) mencadangkan pengetua dan guru besar memainkan peranan yang penting dalam menambahbaikkan serta meningkatkan pencapaian murid dalam pengajaran dan pembelajaran

Pengajaran dan Pembelajaran di rumah (PdPR) adalah alternatif KPM bagi membantu guru melaksanakan pengajaran dalam norma baharu. Tambahan pula, dalam situasi di mana semua individu perlu 'duduk di rumah' seperti yang telah disarankan oleh kerajaan sebagai tindakan yang diperlukan bagi meratakan lengkuk dan mengendalikan penularan penyakit (Sintema, 2020). Oleh yang demikian, PdPr yang dilaksanakan boleh dijalankan di rumah, pusat komuniti atau mana-mana lokasi yang bersesuaian dan mengikut SOP yang ditetapkan. Merujuk kepada panduan PdPR, ianya melibatkan tiga pendekatan iaitu: Pendekatan PdPR dalam talian: adanya capaian internet, penggunaan peranti dan pembelajaran secara realtime menggunakan aplikasi DELima, Google Meet, Zoom, egamification, video, klip audio, eBuku dan rakaman video. Pendekatan PdPR luar talian dengan penggunaan peranti, tablet, telefon pintar tanpa capaian internet. Pendekatan PdPR secara off site iaitu dilaksanakan di Pusat komuniti atau lokasi yang dibenarkan (Kementerian Pendidikan Malaysia, 2020). Pendekatan yang digunakan mestilah mengikut dan mengambil kira kesesuaian kemudahan guru dan murid. Guru mestilah lebih kreatif dan positif dalam mempelbagaikan kaedah PdPR ini. Profesionalisme guru yang lebih kontekstual akan berlaku dengan sokongan pentadbir dan jaringan interaksi bersama PPD dan JPNM. Walaupun kementerian mengambil pelbagai langkah proaktif dengan mewujudkan PdPR untuk membolehkan pengajaran dan pembelajaran terus berlangsung, namun ia perlu dilihat secara menyeluruh dan sistematik dan tidak hanya sekadar menumpukan kepada aspek infrastruktur dan modaliti semata- 
mata (Siti, 2021). Perdana Menteri telah mengambil beberapa langkah proaktif pada tahun 2020 untuk menjajarkan semula Kurikulum Standard Sekolah Rendah dan Menengah (KSSR dan KSSM) untuk disesuaikan dengan situasi pembelajaran yang tidak menentu disebabkan Perintah Kawalan Pergerakan (PKP), dan perintah kawalan bersasar. Namun begitu realiti pelaksanaan PdPR bukanlah sesuatu yang mudah dilaksanakan. Jika terdapat satu murid yang dapat melalui PdPR dengan jayanya, ada sepuluh lagi murid yang berhadapan dengan pelbagai cabaran.

\section{Cabaran Guru dalam Melaksanakan Pengajaran dan Pembelajaran di Rumah}

\section{Cabaran Penggunaan Teknologi}

Pembelajaran yang berkesan, penyampaian kurikulum yang bersandarkan Dokumen Standard Kurikulum Pentaksiran (DSKP), interaksi dua hala guru dan murid dan sokongan daripada Ibu Bapa, pentadbir dan pemimpin merupakan hala tuju dalam memastikan kelangsungan proses pembelajaran dan pengajaran berlaku dengan menggunakan medium secara optimum. Walau bagaimanapun, guru-guru sering kali tidak mendapat penglibatan murid di dalam kaedah PdPR ini atas beberapa sebab antaranya disebabkan oleh situasi semasa dan terpaksa mengambil kira sumber keupayaan yang ada pada murid. Tamilmullai dan Salini (2021) menyatakan skrin telefon bimbit yang kecil juga menjadi satu cabaran kerana apa yang dimuat naik oleh guru semasa pembelajaran secara dalam talian menggunakan google meet mahupun zoom meeting di mana murid tidak dapat dilihat dengan jelas. Kesediaan pelajar mengikuti kelas secara dalam talian adalah bergantung kepada peranti, pelan data dan motivasi diri pelajar.

Cabaran lain yang turut dihadapi apabila kurangnya kemahiran ICT dalam mengakses DELima, Zoom, Google Meet dan pelbagai kaedah PdPR dalam kalangan murid atau ibu bapa. Ini menyebabkan guru perlu memberikan tumpuan masa lebih dalam mengajar murid kepada penggunaan ICT. Jika murid tidak dijelaskan tentang tatacara penggunaan ICT. Motivasi murid akan menurun untuk melaksanakan PdPR. Capaian internet yang rendah di sesetengah lokasi tempat tinggal murid memberi cabaran kepada guru apabila murid 'hilang dari radar' di mana tidak membolehkan murid untuk mengikuti pdpr secara dalam talian manakala murid yang lengkap dengan semua peralatan dan capaian internet tetapi menghadapi cabaran terhadap sikap sambil lewa murid dan kurangnya motivasi menyebabkan murid tidak mahu melibatkan diri dalam PdPR. Menurut laporan kajian 'Covid-19 and Uneqeual Learning' yang dilakukan oleh Khazanah Research Institute (KRI), sebanyak 37 peratus kanak-kanak menghadapi masalah tidak mempunyai kelengkapan peranti seperti komputer riba dan tablet yang boleh digunakan semasa melaksanakan PdPR manakala hanya enam hingga ke sembilan peratus sahaja kanak-kanak yang mempunyai peranti komputer riba sendiri. Masalah kekurangan dan kelengkapan peranti yang tidak mencukupi ini serta capaian internet yang kurang stabil menjejaskan proses PdPR untuk dilaksanakan dengan baik.

Wan (2021) menyatakan bagi mengatasi masalah ini, beberapa negara telah mengambil langkah proaktif dengan mengagihkan peranti-peranti kepada kelas-kelas dan meningkatkan akses kepada talian. Manakala di Negara Finland dan beberapa negeri di China, dan Amerika Syarikat, murid mereka dibenarkan meminjam peranti digital daripada pihak sekolah bagi memudahkan murid untuk mengakses platform pembelajaran secara dalam talian. Dalam kajian yang dijalankan oleh Hapini et al. (2020) menyatakan kajian lepas telah mendedahkan bahawa kebanyakan negara-negara membangun berhadapan dengan masalah yang sama dalam melaksanakan ICT di sekolah. Selain itu, antara perkara lain yang sering diketengahkan ialah isu berkenaan seperti kekurangan dan kelemahan dalam aspek kemudahan fizikal, sokongan dan penyelenggaraan seperti yang berlaku di India, Namibia dan Bangladesh (Jackson, Pompe, \& Krieshok, 2011; M. S. H. Khan, Hasan, \& Clement, 2012; Roy, 2012).

\section{Cabaran Pentadbir, Guru, Murid dan Ibu Bapa}

Cabaran dunia semakin menjadi kompleks dengan adanya perubahan dan perancangan perlu bersifat mudah ubah. Setiap pemimpin pendidikan berperanan berubah mengikut kehendak dan keperluan terkini terutamanya pada zaman milenium. Pentadbir perlu merancang satu pelan tindakan bagi menghadapi 
perubahan era pendidikan ini. Pemimpin perlu mempersiapkan diri dalam segala aspek apabila berhadapan dengan dunia yang berubah-ubah agar dapat mengadaptasi apa jua keadaan (Drucker, 2017).

Menteri Pendidikan Malaysia Dr Radzi Jidin (2021) dalam temubualnya bersama rancangan Bual Bicara Khas Hari Guru bersama Menteri Kanan Pendidikan menyatakan penyediaan kaedah pendigitilan dalam menyampaikan pengajaran memerlukan dasar yang cukup luas bagi membolehkan persediaan latihan struktur kompetensi dapat ditingkatkan. Guru perlu mendapat peluang belajar dan mengambil inisiatif dalam menambah baik pengetahuan dan kemahiran digital untuk menyampaikan ilmu yang dimiliki. Mazura dan Wak Chu Wok (2018) menyatakan sebanyak 80\% guru di sekolah tidak mempunyai pengetahuan yang baik tentang Pdpc terbeza. Hal ini juga menandakan bahawa guru menghadapi cabaran dalam meningkatkan pengetahuan dan kompetensi mereka dengan pendekatan pengajaran berbeza. Tambahan pula, norma baharu menuntut guru untuk bertugas daripada rumah akibat penularan wabak COVID-19 sehingga menyebabkan rutin dan budaya kerja guru juga berubah sepanjang tempoh Perintah Kawalan Pergerakan (PKP) (Rahayu et al. 2020). Rutin kerja guru juga bukan sahaja mengajar tetapi guru perlu meningkatkan pengetahuan dan kemahiran ICT. Petrie (2020) potensi diri guru boleh dikembangkan dengan menghadiri kursus pendidikan, latihan dan program pengembangan melalui beberapa platform dalam talian termasuk platform komunikasi dan kolaborasi terpadu seperti Microsoft Teams, Google Classroom, Canvas dan Blackboard.

Cabaran guru juga bertambah apabila guru berhadapan dengan ibu bapa. Dalam New (2020) seorang pekerja swasta, yang mempunyai anak bersekolah Tahun Satu dan Dua di Selangor menyatakan, terdapat guru yang tidak konsisten dalam sesi pengajaran dimana guru sering bertukar-tukar platform media sosial dan medium pengajaran dalam mengendalikan kelas PdPR, dalam persediaan guru melaksanakan pengajaran sepenuhnya secara dalam talian, Tambahan pula, bahan pengajaran yang digunakan tidak mencukupi kehendak murid dalam melaksanakan PdPR, sistem penjadualan serta alternatif lain kepada pelajar dan guru yang tidak mempunyai akses kepada kemudahan ini. Sebagai contoh, seorang bapa yang mempunyai anak berusia enam, lapan dan sepuluh tahun menyatakan PdPR bukan sahaja menuntut disiplin tinggi pelajar, malah peranan ibu bapa juga perlu penting dalam memastikan anak-anak tidak tercicir dalam mendapatkan akses pendidikan.

Kemampuan ibu bapa dalam menyediakan peranti yang bersesuaian dan akses internet untuk kegunaan pembelajaran anak menjadi cabaran utama. Ibu bapa perlu menyediakan keperluan ini bagi memastikan kelangsungan pendidikan anak-anak mendapat pendidikan secara sama rata. Selain itu, ibu bapa juga perlu membuat pemantauan ke atas anak-anaknya sewaktu melaksanakan PdPR. Ini secara tidak langsung ibu bapa perlu meningkatkan kemahiran mereka dalam penggunaan teknologi. Mohd Norazmi, Faiza \& Ruqia (2021) melalui analisis kajian yang dilakukan, beliau mendapati antara elemen ibu bapa yang mencabar ialah dari segi penyediaan bahan atau kemudahan, pengetahuan, kemahiran dan pengurusan keluarga. Norhayati (2020) menyatakan peluang yang ada semasa PKP sedikit sebanyak dapat memberi mereka masa dan ruang untuk bersama dalam membantu pembelajaran anak-anak mereka. Sumitra dan Roshan (2021) menjelaskan ini secara tidak langsung telah menjalin hubungan yang kuat antara guru dan ibu bapa berbanding sebelumnya. Ibu bapa mula menerima dan membiasakan diri dengan pendidikan norma baharu ini.

Jika sebelum ini penglibatan murid dalam aktiviti PdP kebiasaannya dinilai berdasarkan pemerhatian di dalam bilik darjah. Kriteria-kriteria pemerhatian yang direkodkan dalam senarai semak ialah seperti kekerapan bertanya soalan, menjawab soalan guru, memberikan pendapat dalam kumpulan, membuat pembentangan dan membantu rakan menyelesaikan masalah. Namun apabila pelaksanaan PdPR, hanya guru yang akan bercakap dari awal sehingga akhir kelas dan murid-murid tidak diberi ruang untuk berinteraksi sesama rakan sebaya mereka, meskipun tidak dinafikan bahawa masa dan faktor data juga boleh menjadi salah satu faktor. Selain itu, antara cabaran lain ialah apabila menggunakan waktu PdPR bagi membantu keluarga mereka. Sumitra \& Roshan (2021) sebilangan pelajar menyatakan bahawa mereka harus menjaga ahli keluarga mereka yang sakit dan membawanya ke hospital. 


\section{Perbincangan Kajian}

Hasrat Falsafah Pendidikan Kebangsaaan (FPK) dalam memastikan semua murid mendapat pendidikan secara berterusan dalam memperkembangkan potensi kemenjadian murid yang selari dengan enam aspirasi murid di dalam Pelan Pembangunan Pendidikan Malaysia (PPPM) 2013-2025. Aspirasi ini adalah untuk memastikan semua murid mendapat pengetahuan, kemahiran berfikir, kemahiran memimpin, kemahiran dwibahasa, etika dan kerohanian serta identiti nasional. Kejayaan ini akan tercapai apabila semua pihak memberikan komitmen dalam sistem pendidikan tidak kiralah pendidikan secara bersemuka atau secara dalam talian di rumah. Pelaksanaan pengajaran yang tidak berkesan dan penambahbaikan perlulah diambil tindakan segera oleh semua pihak dan tidak tertumpu kepada satu pihak sahaja. Peranan pentadbir menjadi peranan utama dalam merancang strategi dan cabaran yang dihadapi oleh guru, murid dan ibu bapa.

Guru merupakan tunjang utama dalam sistem pendidikan perlu sentiasa bersedia dalam meningkatkan kompetensi diri dan profesionalisme perguruan. Guru perlu sentiasa bersedia memperbaiki diri dan mengubah pendekatan pengajaran selari dengan perkembangan teknologi dan keperluan kerjaya semasa (Nor Amalina \& Zanaton, 2018). Guru perlu meletakkan dirinya seiring dengan perubahan yang berlaku. Kemahiran dan pengetahuan teknologi dan strategi pendekatan yang digunakan menjadi perkara utama buat semua guru. Strategi kebijaksanaan guru memilih suatu pendekatan dan kecekapan merancang kaedah dan teknik pembelajaran akan memberikan impak yang lebih baik terhadap pemahaman murid dalam proses pembelajaran (Ee, 2003),

Motivasi dalam kalangan murid, guru dan ibu bapa juga perlu dipertingkatkan agar cabaran melaksanakan PdPR dapat diatasi dengan baik. Murid perlu sentiasa diperingatkan dan diberi motivasi serta semangat untuk menjalani PdPR agar momentum untuk terus belajar akan sentiasa ada dalam diri murid. Peranan guru menjadi utama dalam memastikan PdPR ini dapat dilaksanakan.

\section{Kesimpulan}

Secara keseluruhannya, cabaran guru dalam pengajaran dan pembelajaran di rumah terutamanya dalam menyesuaikan diri dengan penggunaan teknologi adalah amat tinggi. Guru perlu memantapkan diri dengan imu pengetahuan yang selaras perkembangan pada masa kini. Perkembangan teknologi dengan pelbagai aplikasi memerlukan guru memberikan komitmen masa dan wang untuk meningkatkan kompetensi dan kemahiran diri. Motivasi dan semangat guru perlu dikekalkan untuk terus mendidik murid-murid serta berusaha untuk mengatasi permasalahan atau kekangan yang dihadapi sewaktu melaksanakan PdP atau PdPR. Kesimpulannya, cabaran PdPR ini tidak hanya ditangani secara bersendiri tetapi ianya memerlukan kerjasama semua pihak. Guru, ibu bapa dan murid perlu memikul tanggungjawab ini dalam memastikan PdPR dapat dilaksanakan dengan jayanya dan secara tidak langsung mencapai hasrat yang terkandung dalam Pelan Pembangunan Pendidikan Malaysia (20132025).

\section{Rujukan}

Athir, I. (2020). PKP: Cabaran Guru Mengajar Di Alam Maya. Dicapai pada 16 April 2020, Dari https://suaramerdeka.com.my/pkp-cabaran-guru-mengajar-di-alam-maya/

Drucker, P (2017). Human Prosperity in a Changing World. Peter Drucker challenge 2017. The future economic man. PDC 2017.

Ee Ah Meng, (2003), "Ilmu Pendidikan: Pengetahuan dun Ketrampilan Ikhtisas". Selangor: Penerbitan Fajar Bakti Sdn. Bhd.

F. Shahatha Al-Mashhadani \& Shakiroh Khamis (2020). Cabaran Dalam Melaksanakan Teknologi Maklumat dan Komunikasi: Analisis Kes Persekitaran Pembelajaran Maya-Frog Serta Strategi Untuk Melestarikan Penggunaan Google Classroom Dalam Kalangan Guru. Journal of Educational Research and Indigenous Studies, 1(1). 
Hallinger, P., \& Murphy, J. F. 1985. Assessing the instructional management behavior of principals. Elementary School Journal, 217-247

Ima Eryanty Abdul Manaf \& Adam Zulkarnain Saleng (2020). Pandemik: Pendekatan Pelaksanaan Latihan. Perpustakaan Negara Malaysia (PNM)

Jackson, S. J., Pompe, A., \& Krieshok, G. (2011). Things Fall Apart: Maintenance, Repair, and Technology for Education Initiatives in Rural Namibia. In iConference '11 (pp. 83-90).

Kementerian Pendidikan Malaysia. (2020). Manual Pengajaran Dan Pembelajaran Di Rumah. Dilihat

Lee, S. M. (1998). Psikologi Pendidikan 2. Edisi 2. Kuala Lumpur: Kumpulan Budiman Sdn. Bhd.

Leithwood, K., Day, C., Sammons, P., Harris, A. \& Hopkins, D. 2006. Seven strong claims about successful school leadership. National College of School Leadership, Nottingham

Mary Yap Kain Ching. (2015). Guru berperanan lahir pelajar capai standard global. Dilihat 28 Februari 2021 dari https://www.bharian.com.my/kolumnis/2015/08/74472/guru-berperanan-lahir-pelajarcapai-standard-gobal

Mazura Sulaiman \& Wak Chu Wok. (2018). Tinjauan tentang pengetahuan dan penerimaan terhadap

Mohd Norazmi bin Nordin, Faiza Iqbal \& Ruqia (2021). Challenges Of Parents In The Implementation

Niqab, M., Sharma, S., Wei, L. M., \& Maulod, S. B. A. (2014). Instructional Leadership Potential among School Principals in Pakistan. International Education Studies, 7, 6.

Nor Amalina Ab Hakim \& Zanaton Iksan. (2018). Pengetahuan, kemahiran pelaksanaan dan sikap guru terhadap pembelajaran berasaskan masalah (PBM) dalam mata pelajaran Sains. Seminar Antarabangsa IsuIsu Pendidikan (ISPEN 2018), pp, 72-82. 5 Julai. Kuala Lumpur: Fakulti Pendidikan, Universiti Malaya.

Nor Hidayati Mokhtar. (2020). Pembelajaran atas talian untuk pembelajaran sepanjang hayat. Retrieved from https://news.utm.my/ms/2020/04/pembelajaran-atas-talian-untuk-pembelajaran-sepanjanghayat/.

Petrie, C. (2020). Spotlight: Quality education for all during COVID-19 crisis (hundred Research Report \#01). United Nations. https://hundred.org/en/collections/qualityeducation-for-all-duringcoronavirus

Rahayu Ahamad Bahtiar, Sham Ibrahim, Halijah Ariffin, Nor Hazimah Ismail \& Wan Mohd Khairul

Roshlawaty Raieh (2020). Realiti Pengajaran dan Pembelajaran di Rumah (PdPR) semasa PKPB: Ini yang perlu kita tahu. Daripada https://www.gpsbestari.com/artikel/rencana/realiti-pengajaran-danpembelajaran-di-rumah-pdpr-semasa-pkpb-ini-yang-perlu-kita-tahu-1.936425

Sintema, E. J. (2020, April 7). Effect of COVID-19 on the performance of grade 12 students:

Siti Nur Diyana Mahmud (2021). Teliti cabaran dihadapi guru, murid dalam PdPR. https://www.bharian.com.my/rencana/minda-pembaca/2021/05/812576/teliti-cabaran-dihadapiguru-murid-dalam-pdpr

Sumitra Pokhrel and Roshan Chhetri (2021). A Literature Review on Impact of COVID-19 Pandemic on Teaching and Learning. Reprints and permissions: in.sagepub.com/journals-permissions-india DOI: 10.1177/2347631120983481journals.sagepub.com/home/hef

Tamilmullai Thannimalai \& Salini Baloh (2021) CABARAN PDPR BAHASA TAMIL DI SEKOLAH LUAR BANDAR. MJSSH Online: Volume 5- Issue 2 (Aprl, 2021), Pages 183 - 190

Wan Isa. (2020). Peranan dan cabaran pemimpin pendidikan dalam memastikan matlamat dan agenda pendidikan dilestari dalam tempoh perintah kawalan pergerakan (PKP) Covid-19. Diakses dari:

https://iab.moe.edu.my/bahanportal/pemberitahuan/2020/2.\%20PERANAN\%20DAN\%20CABA RAN\%20PEMIMPIN\%20PENDIDIKAN.pdf (1 Mei 2021).

Wan Ya Shin (2020) Pendidikan Sepanjang Krisis COVID-19. engurus Penyelidikan, Institut Demokrasi dan Hal Ehwal Ekonomi (IDEAS). April 11, 2020 dari https://www.ideas.org.my/pendidikan-sepanjang-krisis-covid-19/

Waters, J.T, Marzano, R. J \& McNulty, B. 2003. Balanced Leadership: What 30 Years of Research Tell Us About The Effect Of Leadership On Student. Aurora, CO.

Zaid, M., Norazmi, N. \& Abdul Rasid, A. R. (2020). Headmaster Leadership Effect On Task Load Of Special Education Integration Program Teacher. Humanities \& Social Sciences Reviews, 8(2), 451-456. 